\title{
FIRST RECORD OF THE ROUND GOBY, NEOGOBIUS MELANOSTOMUS (ACTINOPTERYGII: PERCIFORMES: GOBIIDAE) IN BELGIUM
}

\author{
Hugo VERREYCKEN ${ }^{1 *}$, Jan J. BREINE ${ }^{1}$, Jos SNOEKS ${ }^{2}$, and Claude BELPAIRE ${ }^{1}$ \\ ${ }^{1}$ Research Institute for Nature and Forest (INBO), Duboislaan 14, B-1560 Hoeilaart, Belgium \\ ${ }^{2}$ Royal Museum for Central Africa (RMCA), Zoology Department, \\ Leuvensesteenweg 13. B-3080 Tervuren, Belgium
}

Verreycken H., Breine J.J., Snoeks J., Belpaire C. 2011. First record of the round goby, Neogobius melanostomus (Actinopterygii: Perciformes: Gobiidae) in Belgium. Acta Ichthyol. Piscat. 41 (2): 137-140.

\begin{abstract}
Almost six years after the first finding of the round goby Neogobius melanostomus (Gobiidae) in the Netherlands, several specimens of this invasive Ponto-Caspian benthic fish were also recorded in the Belgian part of the River Scheldt and in the Albert Canal. This is the first record of the round goby in Belgium.
\end{abstract}

Keywords: River Scheldt, Albert Canal, non-native fish, Ponto-Caspian gobies

The round goby Neogobius melanostomus (Pallas, 1814) is a benthic, euryhaline species of the family Gobiidae, native to central Eurasia including the Black-, Azov-, and Caspian seas. Maximum standard length is $25.0 \mathrm{~cm}$ but smaller sizes are attained in fresh waters (Pinchuk et al. 2003). Diagnostic characteristics of the round goby following Pinchuk et al. (2003) include a completely scaled nape with cycloid scales on the anterior and middle nape (also upper opercle, breast, pectoral fin lobes, and part of abdomen with cycloid scales while the rest of the body has weak ctenoid scales), head depth about equal to width, a lateral line typically with $49-55$ scales, pelvic disc with weakly defined lateral lobes on anterior membrane usually not reaching anus, dorsal fins contiguous and second dorsal fin uniform in height. Most conspicuous is the prominent posterior black spot on the first dorsal fin. This spot does not occur in other Ponto-Caspian gobies except in Neogobius caspius (Eichwald, 1831). The latter species, however, can be easily distinguished from the round goby by e.g., anterior nostrils very close to the upper lip and a lateral line with 58-71 scales (Pinchuk and Miller 2003).

The Ponto-Caspian round goby was transported with ballast water to different parts of Europe and North America (Corkum et al. 2004). In the Netherlands, van Beek (2006) reported the first record in 2004 and recent fish surveys have shown that the species is now widespread and abundant in the Dutch Rhine and Meuse delta (Spikmans and van Kessel 2010). The only other westernEuropean country with populations of $N$. melanostomus seems to be Germany where it occurs in the river Danube and in the Baltic Sea (Kottelat and Freyhof 2007). Other (North, Central and East) European countries with records of introduced round goby include Austria (Mühlegger et al. 2010), Poland (Grabowska et al. 2010), Czech Republic (Lusk et al. 2010), Hungary (Borza et al. 2009), Slovakia (Stráňai and Andreji 2004), Bulgaria (Polacik et al. 2008), Serbia, Romania, Estonia, and Sweden (Froese and Pauly 2010).

The round goby was recorded for the first time in Belgian waters in the tidal, mesohaline part (three to four pro mille salinity at the time of sampling) of the River Scheldt near Liefkenshoektunnel (lat $51^{\circ} 17^{\prime} 27.75^{\prime \prime} \mathrm{N}$, long $4^{\circ} 18^{\prime} 05.74^{\prime \prime} \mathrm{E}$ ) (Fig. 1) on 8 April 2010. The first specimen found measured $10.5 \mathrm{~cm}$ total length (TL) (Fig. 2) and was caught in a paired fyke net. The fykes were placed in the River Scheldt in the framework of a fish monitoring programme of the Research Institute for Nature and Forest. Only two months after this discovery, 12 specimens of the round goby were caught by an angler on three occasions $(8,15$, and 24 June 2010) in the Albert Canal near Hasselt (approx. lat 50 $56^{\prime} 59^{\prime \prime} \mathrm{N}$, long $5^{\circ} 19^{\prime} 18^{\prime \prime} \mathrm{E}$ ) (Fig. 1). Two of those 12 specimens mentioned above were given to the first author (9.3 and $10.6 \mathrm{~cm}$ TL, respectively). The remaining ones were photographed and released. On 29 June 2010, another specimen $(5.2 \mathrm{~cm} \mathrm{TL})$ was caught in a fyke net in the River Scheldt near Zandvliet (lat 51²2'57.3' $\mathrm{N}$, long $\left.4^{\circ} 14^{\prime} 15.52^{\prime \prime} \mathrm{E}\right)$ (Fig. 1).

The first caught specimen was carefully examined and identified as the genus Neogobius following Miller and Vasil'eva (2003) and further diagnosed as N. melanostomus following Pinchuk et al. (2003). The morphometric characteristics and meristics of this specimen of N. melanostomus (Table 1) were similar to those reported in the literature (Pinchuk et al. 2003). This specimen has

\footnotetext{
${ }^{*}$ Correspondence: Hugo Verreycken, Instituut voor Natuur- en Bosonderzoek (INBO), Duboislaan 14, B-1560 Hoeilaart, Belgium, phone: +32 2 6580426, fax: +32 2 6579682, e-mail: hugo.verreycken@inbo.be
} 
been deposited in the Royal Belgian Institute of Natural Sciences (Brussels, Belgium) as reference material (1 specimen, $105.1 \mathrm{~mm}$ TL, location: Liefkenshoektunnel, Scheldt, collection reference: KBIN 24.768).

While ballast water transport was an important vector for the rapid spreading of the round goby over long distances, also active migration was suggested as a colonization route. This was facilitated by the opening of the MainDanube Canal in 1992 which connected the Rhine and Danube river systems and thus enabling Ponto-Caspian species to move actively to West-Europe (Copp et al. 2005). As in the Netherlands (van Beek 2006), it is likely that round gobies were released in the lower part of the River Scheldt (within the proximity of the international harbour of Antwerp) with ballast water disposal. It cannot be ruled out, however, that also active migration of specimens from the dense populations in the Dutch Rhine delta through the Rhine-Scheldt Canal (Fig. 1) has taken place. The specimens recorded in the purely freshwater Albert Canal almost certainly must have reached there as a result of natural dispersal as there is no transport of sea vessels. The distance between the locations on the lower River Scheldt and the Albert Canal is about $100 \mathrm{~km}$ making active migration (Kornis and Vander Zanden 2010) a possible explanation even with three ship locks in this section. It is unlikely that the round gobies were used (illegally) by anglers as live bait and released after fishing. The catches of 12 round gobies by an angler in the Albert Canal suggest that this gobiid is probably already abundant in certain parts of this canal. The Albert Canal constitutes the main corridor between the two largest river systems in Belgium namely the Rivers Meuse and Scheldt. Hence, we predict that due to the strategic position of the Albert Canal a wide distribution of round goby in Belgium will soon be a fact.

The introduction of N. melanostomus has caused ecological as well as economical problems with well documented cases for the Laurentian Great Lakes (USA and Canada) and for the Gulf of Gdańsk (Poland) (for an overview see Corkum et al. 2004). Main concerns expressed by Corkum et al. (2004) are:

- transfer of contaminants through the food web;

- detrimental effects on native species;

- proliferation due to multiple-spawning habits;

- potential expansion by anglers through use as live bait; and

- economic costs of gobies as bycatch in nets of commercial fishery.

Dorenbosch (2009) suggests that the decline of native bullhead populations of Cottus perifretum Freyhof, Kottelat et Nolte, 2005 and Cottus rhenanus Freyhof, Kottelat et Nolte, 2005 in the Dutch River Rhine since 2000 may be related to a rapid increase in numbers of the Ponto-Caspian gobiids there.

Table 1

Meristics and morphometric characteristics (as percentage of indicated measurements) of the first Neogobius melanostomus specimen caught in Belgium in the Scheldt River near Liefkenshoektunnel (lat $51^{\circ} 17^{\prime} 27.75^{\prime \prime} \mathrm{N}$, long $\left.4^{\circ} 18^{\prime} 05.74^{\prime \prime} \mathrm{E}\right)$ on 8 April 2010

\begin{tabular}{lcc}
\hline & Abbreviation & Measurement \\
Character & $D_{1}$ & $\mathrm{VI}$ \\
\hline First dorsal fin & $D_{2}$ & $\mathrm{I} / 14$ \\
Second dorsal fin & $A$ & $\mathrm{I} / 11$ \\
Anal fin & $l . l$. & 54 \\
Scales in lateral series & $\mathrm{TL}$ & 105.1 \\
Total length [mm] & $\mathrm{SL}$ & 85.2 \\
Standard length [mm] & $l c$ & 28.5 \\
Head length & $l a c$ & 20.8 \\
Head width & $h$ & 12.8 \\
Least depth of caudal peduncle (min. body depth) & $h c$ & 22.5 \\
Head depth at nape & $l p c$ & 17.2 \\
Length of caudal peduncle & $p D_{1}$ & 32.9 \\
Predorsal distance (snout to vertical of $D_{1}$ ) & $p D_{2}$ & 53.1 \\
Predorsal distance (snout to vertical of $D_{2}$ ) & $p A$ & 57.5 \\
Snout to vertical of anal fin origin & $p V$ & 30.5 \\
\hline Snout to vertical of pelvic fin (disc) origin & $p r O$ & 32.1 \\
\hline \multirow{2}{*}{$\quad$ Preorbital distance (snout length) } & $O h$ & 22.7 \\
\hline Horizontal diameter of eye & $p o O$ & 50.6 \\
\hline
\end{tabular}

Note: Spinous rays in Roman letter type, articulated rays in Arabic letter type. 
Apart from the round goby, other gobiid species from the Ponto-Caspian region may be expected in the near future in Belgium (Verreycken et al. 2007) as was the case in the Netherlands where western tubenose goby, Proterorhinus semilunaris (Heckel, 1837), settled in the Dutch Rhine system in 2002; round goby in 2004; bighead goby, Ponticola kessleri (Günther, 1861), in 2007; and monkey goby, Neogobius fluviatilis (Pallas, 1814), in 2009 (van Kessel et al. 2009).
In order to reduce the establishment, expansion and impact of non-native and invasive species in Belgium, a draft of the Royal decree on the import, export, transit and possession of invasive alien species was prepared in 2009. This decree prohibits the possession and transport of live specimens of some invasive non-native species in Belgium e.g. Amur (or Chinese) sleeper Perccottus glenii Dybowsky, 1877 and also the round goby. However, this proposal has not been endorsed yet. Hopefully it will soon

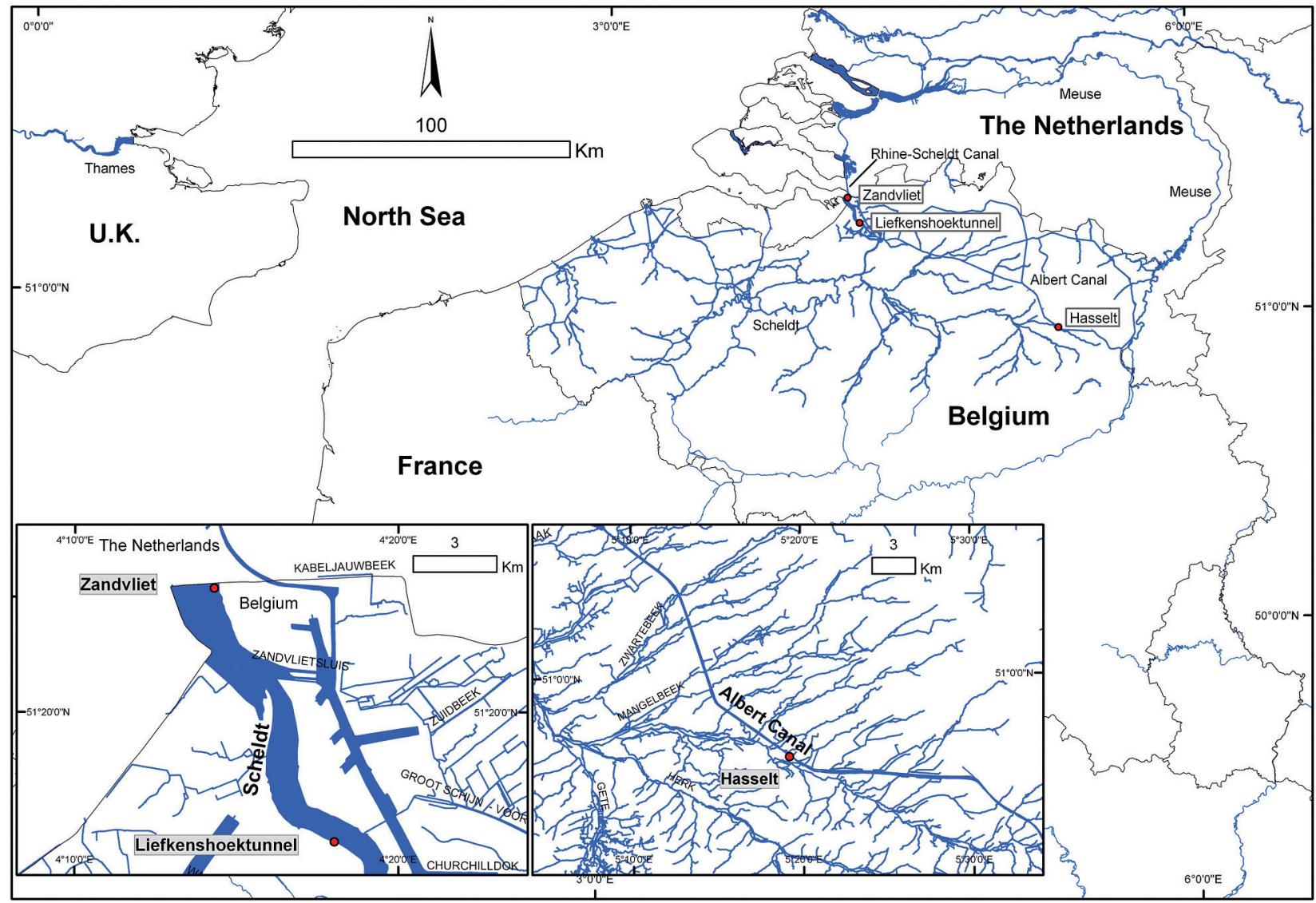

Fig. 1. Locations of first records of Neogobius melanostomus in Belgium $(\bullet)$ with indication of main rivers and canals

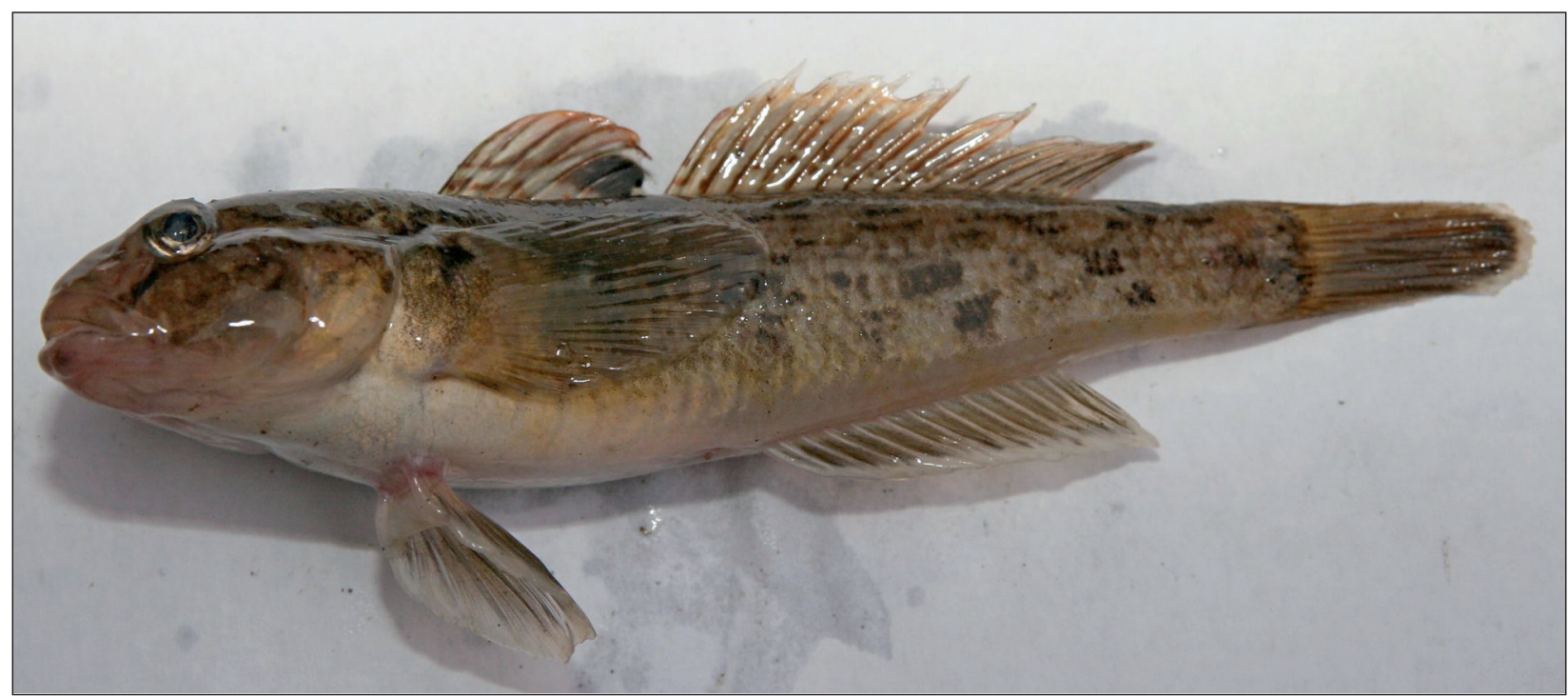

Fig. 2. First recorded specimen of Neogobius melanostomus in Belgium (10.5 cm TL) 
come in force to effectively help to prevent further spreading and reduce potential impacts.

\section{ACKNOWLEDGEMENTS}

We are grateful to Hubert De Wilde for reporting the first specimen from the River Scheldt and to Gustaaf Put for providing us with the specimens of the Albert Canal. Map generating by Yves Maes is greatly appreciated.

\section{REFERENCES}

Borza P., Erös T., Oertel N. 2009. Food resource partitioning between two invasive Gobiid species (Pisces, Gobiidae) in the littoral zone of the River Danube, Hungary. International Review of Hydrobiology 94 (5): 609-621. DOI: 10.1002/iroh.200911134.

Copp G.H., Bianco P.G., Bogutskaya N.G., Erös T., Falka I., Ferreira M.T., Fox M.G., Freyhof J., Gozlan R.E., Grabowska J., Kováč V., Moreno-Amich R., Naseka A.M., Peňáz M., Povž M., Przybylski M., Robillard M., Russell I.C., Stakẻnas S., Šumer S., Vila-Gispert A., Wiesner C. 2005. To be, or not to be, a non-native freshwater fish? Journal of Applied Ichthyology 21 (4): 242-262. DOI: 10.1111/j.1439-0426.2005.00690.x.

Corkum L.D., Sapota M.R., Skora K.E. 2004. The round goby, Neogobius melanostomus, a fish invader on both sides of the Atlantic Ocean. Biological Invasions 6 (2): 173-181. DOI: 10.1023/B:BINV.0000022136.43502.db.

Dorenbosch M. 2009. Population increment of native and alien fish species in the Dutch rivers Rhine and Meuse: Competition and relations with environmental variables. In: Proceedings of 16th ICAIS conference, 19-23 April 2009, Montreal, Canada. http://www.icais.org/html/previous16th.html.

Froese R., Pauly D. (eds.) 2010. FishBase. [version 05/2010] http://www.fishbase.org.

Grabowska J., Kotusz J.,Witkowski A. 2010. Alien invasive fish species in Polish waters: an overview. Folia Zoologica 59 (1): 73-85.

Kornis M.S., Vander Zanden M.J. 2010. Forecasting the distribution of the invasive round goby (Neogobius melanostomus) in Wisconsin tributaries to Lake Michigan. Canadian Journal of Fisheries and Aquatic Science 67 (3): 553-562. DOI: $10.1139 / \mathrm{F} 10-002$.

Kottelat M., Freyhof J. 2007. Handbook of European freshwater fishes. Kottelat and Freyhof, Cornol, Switzerland, Berlin, Germany.

Lusk S., Lusková V., Hanel L. 2010. Alien fish species in the Czech Republic and their impact on the native fish fauna. Folia Zoologica 59 (1): 57-72.

Miller P.J., Vasil'eva E.D. 2003. Neogobius Iljin, 1927. Pp. 163-171. In: Miller P.J. (ed.) The freshwater fishes of
Europe. V. 8/I. Mugilidae, Atherinidae, Atherinopsidae, Blenniidae, Odontobutidae, Gobiidae 1. AULA-Verlag, Wiebelsheim, Germany.

Mühlegger J.M., Jirsa F., Konecny R., Frank C. 2010. Parasites of Apollonia melanostoma (Pallas 1814) and Neogobius kessleri (Guenther 1861) (Osteichthyes, Gobiidae) from the Danube River in Austria. Journal of Helminthology 84 (1): 87-92. DOI: 10.1017/S0022149X09990095.

Pinchuk V.I., Miller P.J. 2003. Neogobius caspius (Eichwald, 1831). Pp. 173-180. In: Miller P.J. (ed.) The freshwater fishes of Europe. V. 8/I. Mugilidae, Atherinidae, Atherinopsidae, Blenniidae, Odontobutidae, Gobiidae 1. AULA-Verlag, Wiebelsheim, Germany.

Pinchuk V.I., Vasil'eva E.D., Vasil'ev V.P., Miller P.J. 2003. Neogobius melanostomus (Pallas, 1814). Pp. 293-345. In: Miller P.J. (ed.) The freshwater fishes of Europe. V. 8/I. Mugilidae, Atherinidae, Atherinopsidae, Blenniidae, Odontobutidae, Gobiidae 1. AULA-Verlag, Wiebelsheim, Germany.

Polačik M., Trichkova T., Janáč M., Vassilev M., Jurajda P. 2008. The ichthyofauna of the shoreline zone in the longitudinal profile of the Danube River, Bulgaria. Acta Zoologica Bulgarica 60: 77-88.

Spikmans F., van Kessel N. 2010. Plaag/risico analyses en habitatgebruik van exoten in de grote rivier. [Nuissance/risk analysis and habitat use of exotics in the large river.] In: 26th Meeting of Vissennetwerk, 3 June 2010, Bilthoven, the Netherlands. http://www.vissennetwerk.nl/bijeenkomsten/?page=detail\&id= $=32$ [In Dutch.]

Stráňai I., Andreji J. 2004. The first report of round goby, Neogobius melanostomus (Pisces, Gobiidae) in the waters of Slovakia. Folia Zoologica 53 (3): 335-338.

van Beek G.C.W. 2006. The round goby Neogobius melanostomus first recorded in the Netherlands. Aquatic Invasions 1 (1): 42-43. DOI: 10.3391/ai.2006.1.1.10.

van Kessel N., Dorenbosch M., Spikmans F. 2009. First record of Pontian monkey goby, Neogobius fluviatilis (Pallas, 1814), in the Dutch Rhine. Aquatic Invasions 4 (2): 421-424. DOI: 10.3391/ai.2009.4.2.24.

Verreycken H., Anseeuw D., Van Thuyne G., Quataert P., Belpaire C. 2007. The non-indigenous freshwater fishes of Flanders (Belgium): Review, status and trends over the last decade. Journal of Fish Biology 71 (suppl. D): 160-172. DOI: $10.1111 /$ j.1095-8649.2007.01679.x.

Received: 10 September 2010 Accepted: 28 January 2011 Published electronically: 30 June 2011 